\title{
Effect of Ni or Co Addition to Sn-Ag Solder on Microstructure and Joint Strength at Interface
}

\author{
Hiroshi Nishikawa ${ }^{1}$, Akira Komatsu ${ }^{2, *}$ and Tadashi Takemoto ${ }^{1}$ \\ ${ }^{1}$ Joining and Welding Research Institute, Osaka University, Osaka 567-0047, Japan \\ ${ }^{2}$ Graduate school of Engineering, Osaka University, Osaka 565-0081, Japan
}

\begin{abstract}
Among various lead-free alloys, $\mathrm{Sn}-\mathrm{Ag}(-\mathrm{Cu})$ system solders are considered the most promising lead-free solders for both wave and reflow soldering technology. Moreover, to improve the characteristics of lead-free solders, the effect of the addition of minor elements to lead-free solders on the properties of solder and interfacial reactions have been studied. The purpose of this research was to investigate the addition of Ni or Co to the Sn-Ag solder on the microstructure and the joint strength of the interface with metallization layer of the substrate. As a metallization layer of the substrate, bare $\mathrm{Cu}$ and electroless Ni-P plating were used. For the reflow process, test samples were heated in a radiation furnace at $523 \mathrm{~K}$ for $60 \mathrm{~s}$, and for the aging process, some samples were heat-treated in an oil bath at $423 \mathrm{~K}$ for $168 \mathrm{~h}, 504 \mathrm{~h}$ and $1008 \mathrm{~h}$. Results show the addition of $\mathrm{Ni}$ or $\mathrm{Co}$ was effective for the IMC formation and growth at the interface with a Cu pad during reflow and aging process, and the addition of $\mathrm{Co}$, except $\mathrm{Ni}$, affected the pull strength of the solder joint with electroless Ni-P plating during aging process. [doi:10.2320/matertrans.MF200851]
\end{abstract}

(Received January 8, 2008; Accepted March 21, 2008; Published May 14, 2008)

Keywords: lead-free solder, minor element addition, interface, microstructure, joint strength, intermetallic compound

\section{Introduction}

Soldering is widely used to connect electronic devices to printed circuit boards. The EU RoHS directive dictated that products sold in the EU must be lead-free from July 1, 2006. ${ }^{1)}$ Then, the manufacturing, performance, and reliability criteria for solder joints have become increasingly complex as relationships between the solder alloy, the circuit board materials and construction. Many alloys are being investigated as substrates for $\mathrm{Sn}-\mathrm{Pb}$ eutectic solder. ${ }^{2,3)}$ In order to develop lead-free soldering technology, considerable research efforts into characteristics of lead-free solder such as the microstructure, mechanical properties and interfacial reactions are in progress. ${ }^{4-10)}$ Among various lead-free alloys, $\mathrm{Sn}-\mathrm{Ag}(-\mathrm{Cu})$ system solders are currently considered the most promising lead-free solders for both wave and reflow soldering technology.

The high reaction rate of metals in molten lead-free solders (the high dissolution rate of metals) was pointed out as the basic characteristic of lead-free solders. For example, Takemoto et al. ${ }^{11)}$ showed that the dissolution of iron in molten solder did occur and the dissolution of iron in leadfree solders was greater than that in the conventional $\mathrm{Sn}-\mathrm{Pb}$ eutectic solder. And they found that the addition of $\mathrm{Fe}$ to $\mathrm{Sn}$ $3.5 \mathrm{Ag}$ solder effectively reduces the dissolution rate of iron. Nishikawa et al. ${ }^{12)}$ investigated the reaction between Sn-Ag$\mathrm{Cu}$ solder and plated iron to reveal the effect of iron-plating conditions on reactions in molten solder. As a result, it was clear that the dissolution of plated iron into molten lead-free solders was largely attributable to the grain size of the plated surface and the dissolution rate decreased with the increase in the grain size. Then, the effect of the addition of Co to Sn$3.5 \mathrm{Ag}$ solder on the dissolution of plated iron was investigated, ${ }^{13)}$ rather than the addition of $\mathrm{Fe}$, and the results

*Graduate Student, Osaka University. Present address: TOSHIBA CORPORATION clearly showed that the addition of Co to $\mathrm{Sn}-3.5 \mathrm{Ag}$ solder was effective in reducing the dissolution thickness of plated iron. Additionally, a reaction test between Co-added solders and phosphorous-deoxidized copper plate was performed, and it was found that the thickness of intermetallic compound (IMC) formed at the interface between $\mathrm{Sn}$-Ag-Co solder and copper plate drastically increased compared with the case of binary $\mathrm{Sn}-3.5 \mathrm{Ag}$ solder, regardless of Co content in the reflow process. Moreover, to improve the characteristics of lead-free solders, the effect of the addition of minor elements such as $\mathrm{Ni}, \mathrm{Co}, \mathrm{In}, \mathrm{Zn}, \mathrm{Ge}, \mathrm{La}, \mathrm{Ce}$ to lead-free solders on the properties of solder and interfacial reactions have been explored in the world. ${ }^{14-20)}$ Chaung et al. ${ }^{17)}$ investigated the IMCs formed during the reflow and aging of Sn-3.0Ag- $0.5 \mathrm{Cu}$ solder and $\mathrm{Sn}-3.0 \mathrm{Ag}-0.5 \mathrm{Cu}-0.06 \mathrm{Ni}-0.01 \mathrm{Ge}$ solder ball grid array (BGA) packages with $\mathrm{Au} / \mathrm{Ni}$ surface finishes. They reported that the growth thickness of the interfacial intermerallic layers and the consumption of the $\mathrm{Ni}$ surfacefinished layer on the $\mathrm{Cu}$ pads in $\mathrm{Sn}-3.0 \mathrm{Ag}-0.5 \mathrm{Cu}-0.06 \mathrm{Ni}-$ $0.01 \mathrm{Ge}$ solder joints are both slightly less than those in $\mathrm{Sn}-$ 3.0Ag-0.5Cu.

The formation of IMCs in solid/liquid reaction couples are primarily controlled by the dissolution processes of base metals. It is well known that the presence of the IMCs between solders and base metals is an indication of good metallurgical joint. However, the IMC thickness of the interface between the solder and substrate is very important for the reliability of the solder joint. The thick IMC layer is generally sensitive to stress and provides sites of initiation and paths of propagation for cracks, since such layer is brittle. From the viewpoint of electronic package reliability, it is significant to understand the relationship between the morphology at the interface and the joint strength. Then, due to the rapid formation of $\mathrm{Cu}-\mathrm{Sn}$ IMC at the tin-based solder $/ \mathrm{Cu}$ interface during the soldering process, the reliability of this type of solder joint is a concern. ${ }^{21)}$ Therefore the electroless nickel-phosphorous (Ni-P) layer was, in some 
(a)

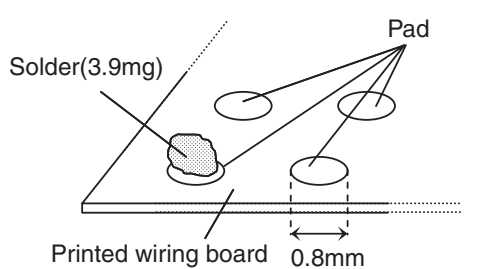

(b)

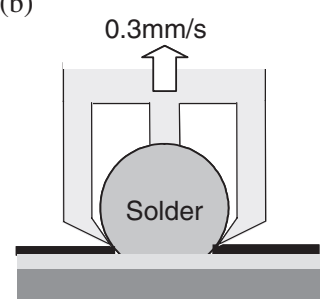

Fig. 1 Schematic diagram of test specimen and bump pull test. (a) Test specimen, (b) Pull test method for solder bump.

instances, deposited on the $\mathrm{Cu}$ substrate as a diffusion barrier between $\mathrm{Cu}$ and the solder materials. ${ }^{22,23)}$ In this study, the microstructure at the interface and the pull strength of Sn$\mathrm{Ag}(-\mathrm{Ni}$ or $\mathrm{Co})$ solder with a $\mathrm{Cu}$ pad and with a nickelphosphorous (Ni-P) metallization was studied in order to clarify the effect of the addition of the minor element, $\mathrm{Ni}$ or $\mathrm{Co}$, on the formation of IMC at the interface and the joint strength.

\section{Experiments}

In this study, binary $\mathrm{Sn}-3.5$ mass $\% \mathrm{Ag}$ solder was used as the basic solder and Sn-3.5 mass \% Ag-0.1 mass $\% \mathrm{Ni}, \mathrm{Sn}-3.5$ mass $\%$ Ag-0.1 mass\%Co and Sn-3.5 mass\%Ag-0.3 mass\%Co were specially prepared as the solder added minor elements. The FR-4 (square $40 \mathrm{~mm} \times 40 \mathrm{~mm}, 25$ pads) was selected as the test board material. Figure 1 shows the schematic diagram of test specimen and bump pull test. The pads of the substrates used in this study comprised two different metallization layers, i.e. bare $\mathrm{Cu}$ and electroless Ni-8 mass\% $\mathrm{P}(5 \mu \mathrm{m}) /$ immersion $\mathrm{Au}$ over an underlying $\mathrm{Cu}$ pad. The diameter of the pad was $0.8 \mathrm{~mm}$. After the test board was immersed in a $4 \% \mathrm{HCl}$ solution for $120 \mathrm{~s}$ and rinsed with ethanol solution, solders $(3.9 \mathrm{mg})$ treated with activated flux were put on each pad. The test board was then placed in a radiation furnace with a nitrogen atmosphere. In the reflow process, the solder was preheated at $373 \mathrm{~K}$ for $120 \mathrm{~s}$ and subsequently heated at $523 \mathrm{~K}$ for $60 \mathrm{~s}$. The solder bump had a height of approximately $1.1 \mathrm{~mm}$ on average. After the reflow process, for aging process, some test samples were heattreated in an oil bath at $423 \mathrm{~K}$ for $168 \mathrm{~h}, 504 \mathrm{~h}$ and $1008 \mathrm{~h}$.

A scanning electron micrograph (SEM) was used to observe the interface between the solder and substrate. All SEM images were obtained using the backscattered electron mode. The thickness of the IMC at the interface was measured using a SEM or an optical microscope. An optical microscope was used to observe the fracture surface after the pull test. An electron probe microanalyzer (EPMA) was used to determine the composition of the IMC. The solder bump was subjected to a pull test using a bump pull tester (Rhesca Co., STR-1000, Japan). The pull speed was fixed at $0.3 \mathrm{~mm} / \mathrm{s}$ for all samples. The pull strength of each condition was estimated by the average of 15 trials.

\section{Results and Discussion}

\subsection{Formation and growth of IMC at the interface}

Figure 2 shows the backscattered electron images of the

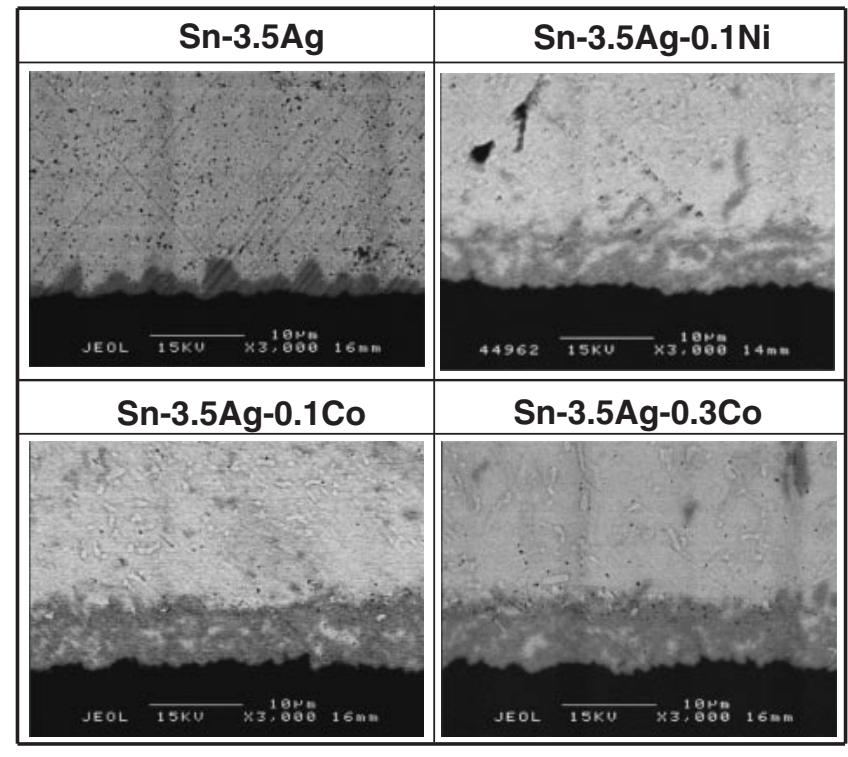

$10 \mu \mathrm{m}$

Fig. 2 SEM photographs of the interface between the solder and $\mathrm{Cu}$ pad just after reflow at $523 \mathrm{~K}$ for $60 \mathrm{~s}$.

cross section of the $\mathrm{Sn}-\mathrm{Ag}(-\mathrm{Ni}$ or $\mathrm{Co})$ solder/Cu pad interface obtained after the reflow process at $523 \mathrm{~K}$ for $60 \mathrm{~s}$. These pictures show the presence of IMCs at the interface between the solder and a $\mathrm{Cu}$ pad. Two types of IMCs can be observed. The morphology of the IMC at the interface of the Sn-Ag-Ni or Co solders was quite different from that for the binary $\mathrm{Sn}$ $\mathrm{Ag}$ solder. In the case of the binary $\mathrm{Sn}-\mathrm{Ag}$ solder, the intermetallic layer in the shape of typical scallop was formed between the solder and $\mathrm{Cu}$ pad. This intermetallic was identified to be $\mathrm{Cu}_{6} \mathrm{Sn}_{5}$ by EPMA analysis. In contrast, at the interface of the ternary $\mathrm{Sn}-\mathrm{Ag}-\mathrm{Ni}$ or Co solders, the IMC layer had coral-like morphology, ${ }^{15)}$ and some portions of solders were trapped in the IMC layer. By EPMA analysis, it was found that the IMC layer contained $\mathrm{Ni}$ or $\mathrm{Co}$ element added to the solder, which was enriched especially at the outer region of the IMC layer. The IMC phase was respectively confirmed as $(\mathrm{Cu}, \mathrm{Ni})_{6} \mathrm{Sn}_{5}$ and $(\mathrm{Cu}, \mathrm{Co})_{6} \mathrm{Sn}_{5}$. The same tendency concerning IMC formation had been found in the previous study using phosphorous-deoxidized copper plate. ${ }^{13)}$ In other recent study, ${ }^{24)}$ the thermodynamic models were applied in order to analyze the influence of additives during the interfacial reaction and the interaction parameters were predicted to evaluate the affinity among the component elements. As a result, the affinities of $\mathrm{Sn}-\mathrm{Ni}$ and $\mathrm{Sn}-\mathrm{Co}$ were higher than that of the $\mathrm{Sn}-\mathrm{Cu}$ couple. That could explain qualitatively why both $\mathrm{Ni}$ and $\mathrm{Co}$ were involved in the IMCs of $\mathrm{Cu}_{6} \mathrm{Sn}_{5}$.

Figure 3 shows the backscattered electron images of the cross section of the $\mathrm{Sn}-\mathrm{Ag}(-\mathrm{Ni}$ or Co) solder/elecroless Ni-P plating interface obtained after the reflow process at $523 \mathrm{~K}$ for $60 \mathrm{~s}$. As shown in this figure, there is little effect of the $\mathrm{Ni}$ or Co addition to the solder on the morphology of the IMC layer at the interface. Regardless of the minor element addition, the complicated thin IMC layer was formed at the interface. In the case of the addition of Co, some particles of IMCs were observed in the solder matrix. By using EPMA, 


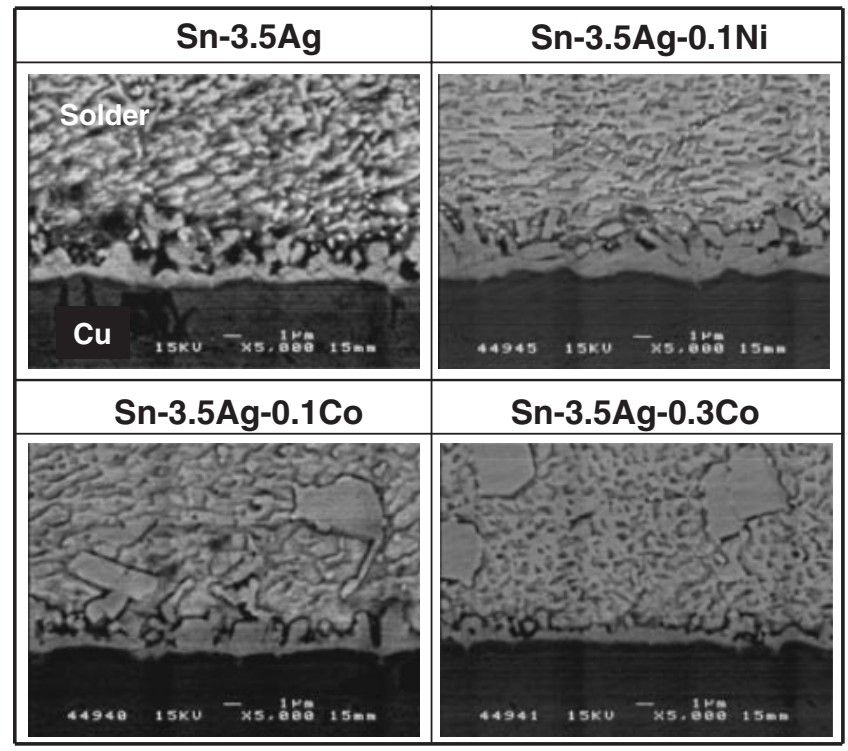

$10 \mu \mathrm{m}$

Fig. 3 SEM photographs of the interface between the solder and Ni-P plating just after reflow at $523 \mathrm{~K}$ for $60 \mathrm{~s}$.
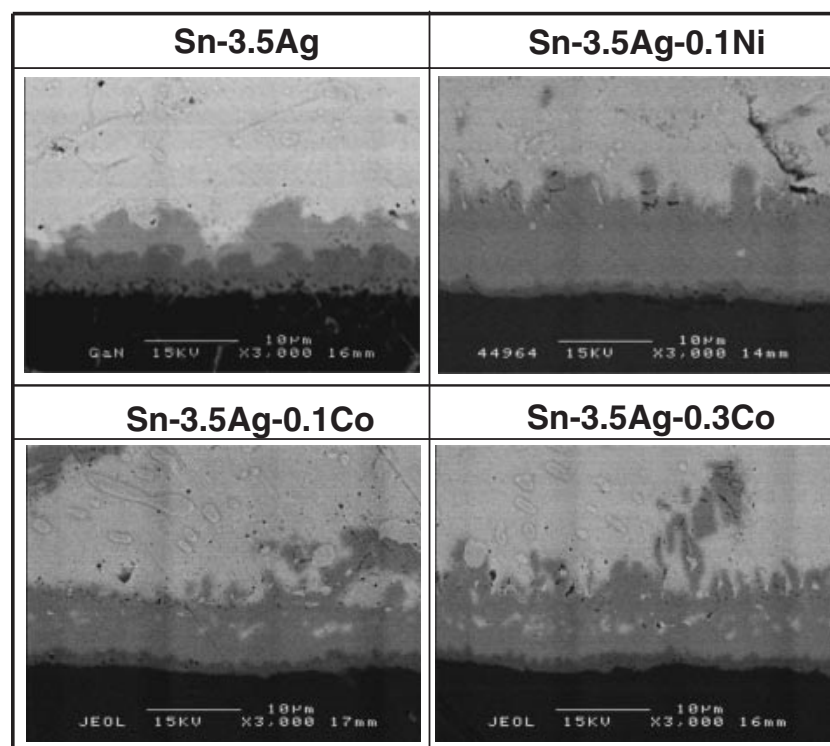

Sn-3.5Ag-0.3Co

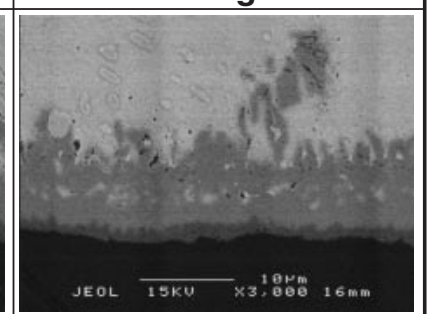

$10 \mu \mathrm{m}$

Fig. 4 SEM photographs of the interface between the solder and $\mathrm{Cu}$ pad after aging for $1008 \mathrm{~h}$ at $423 \mathrm{~K}$.

the composition of the IMCs at the interface and in the solder matrix was analyzed. In the cases of $\mathrm{Sn}-\mathrm{Ag}$ solder and $\mathrm{Sn}$ $\mathrm{Ag}-\mathrm{Ni}$ solder, it was found that the IMC of $\mathrm{Ni}_{3} \mathrm{Sn}_{4}$ was formed at the interface. In the case of Sn-Ag-Co solder, the IMC of $\mathrm{Ni}_{3} \mathrm{Sn}_{4}$ contained a little Co element was formed at the interface, Concerning the IMC particles in the solder matrix, the composition was confirmed as $\mathrm{CoSn}_{2}$.

The backscattered electron images of the interface between the $\mathrm{Sn}-\mathrm{Ag}(-\mathrm{Ni}$ or $\mathrm{Co}$ ) solder and a $\mathrm{Cu}$ pad after aging process at $423 \mathrm{~K}$ for $1008 \mathrm{~h}$ were shown in Fig. 4. The growth of the IMC at the interface of the $\mathrm{Sn}-\mathrm{Ag}-\mathrm{Ni}$ or Co solders was quite different from that for the binary $\mathrm{Sn}-\mathrm{Ag}$ solder as well as just after reflow process. For the binary $\mathrm{Sn}-\mathrm{Ag}$ solder, the

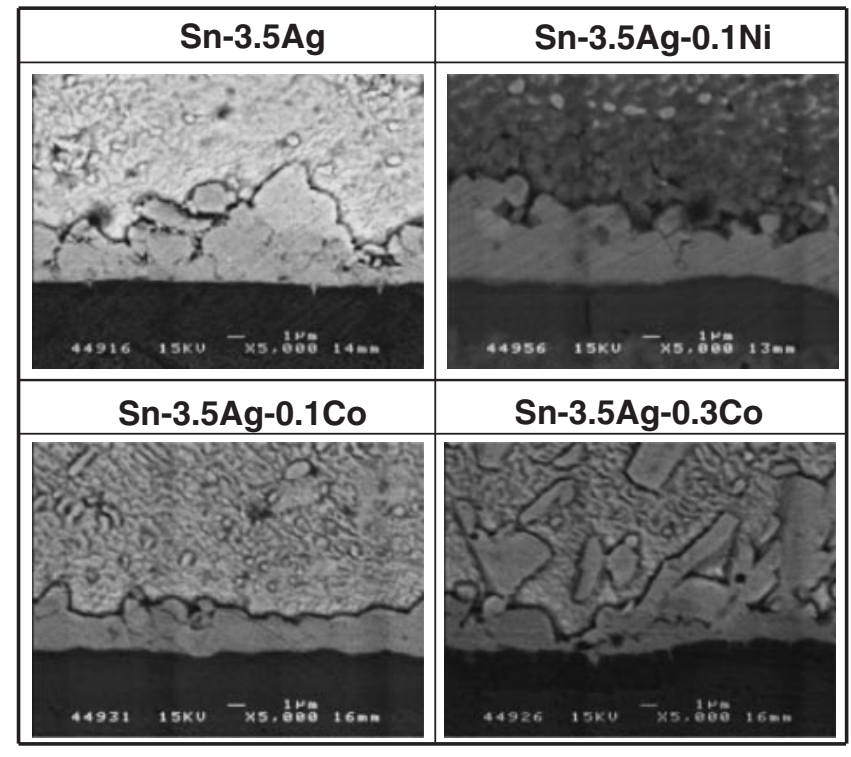

$10 \mu \mathrm{m}$

Fig. 5 SEM photographs of the interface between the solder and Ni-P plating after aging for $1008 \mathrm{~h}$ at $423 \mathrm{~K}$.

morphology of the IMC layer became smooth, and the thick second layer, that was darker phase adjacent to the $\mathrm{Cu}$ pad, was clearly observed at the interface. The layer adjacent to the $\mathrm{Cu}$ pad was $\mathrm{Cu}_{3} \mathrm{Sn}$. For the $\mathrm{Sn}-\mathrm{Ag}-\mathrm{Ni}$ or Co solders, portions of solder trapped in the IMC layer tended to disappear. The very thin second layer, $\mathrm{Cu}_{3} \mathrm{Sn}$, was found at the interface between the $\mathrm{Cu}$ pad and the first layer, $\mathrm{Cu}_{6} \mathrm{Sn}_{5}$, and the $\mathrm{Cu}_{3} \mathrm{Sn}$ intermetallic layer at the interface of the Sn$\mathrm{Ag}-\mathrm{Ni}$ or Co solder grew much more slowly than that of the Sn-Ag solder.

The backscattered electron images of the interface between the $\mathrm{Sn}-\mathrm{Ag}(-\mathrm{Ni}$ or $\mathrm{Co})$ solder and an elecroless Ni-P plating after aging process at $423 \mathrm{~K}$ for $1008 \mathrm{~h}$ were shown in Fig. 5. Compared to the IMC layer just after reflow process shown in Fig. 3, the intermetallic layer at the interface clearly grew and became thick regardless of the solder composition. The effect of the minor element addition to the solder on the growth of the IMC layer was not clear.

Figure 6 shows the total thickness of IMC layers at the interface between the solder and $\mathrm{Cu}$ pad as a function of solder composition and the aging time. Just after reflow process, aging time is $0 \mathrm{~h}$, the IMC thicknesses for the Sn-Ag$\mathrm{Ni}$ or Co solder were much thicker than that for the binary Sn$\mathrm{Ag}$ solder. This means that adding $\mathrm{Ni}$ or Co to the solder enhances the IMC formation during the reflow process. The IMC thicknesses for the Sn-Ag-Ni or Co solder were almost similar in all the solder added the minor element. According to work by other researches, ${ }^{15)}$ it has been pointed out that the solidification catalyst effect of Co promotes reduced undercooling and seems to enhance the nucleation site density of the $\mathrm{Cu}_{6} \mathrm{Sn}_{5}$. And as mentioned in the previous study, ${ }^{13)} \mathrm{Co}$ may be an effective nucleation site for the $\mathrm{Cu}_{6} \mathrm{Sn}_{5}$ phase and the addition of Co to the solder appears to enhance the formation of the IMC phase in the solder. Ni may have a similar effect, too. Hence, IMC containing $\mathrm{Ni}$ or $\mathrm{Co}$ is deposited on the $\mathrm{Cu}_{6} \mathrm{Sn}_{5}$ layer, and the IMC thickness for the 


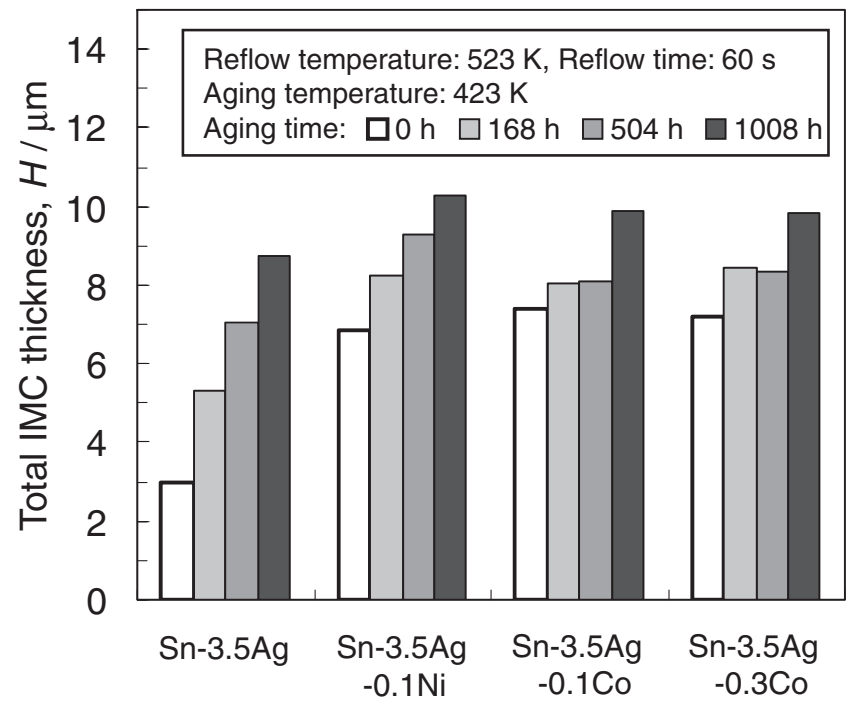

Fig. 6 Effect of aging time at $423 \mathrm{~K}$ on the total IMC thickness between the solder and $\mathrm{Cu}$ pad.

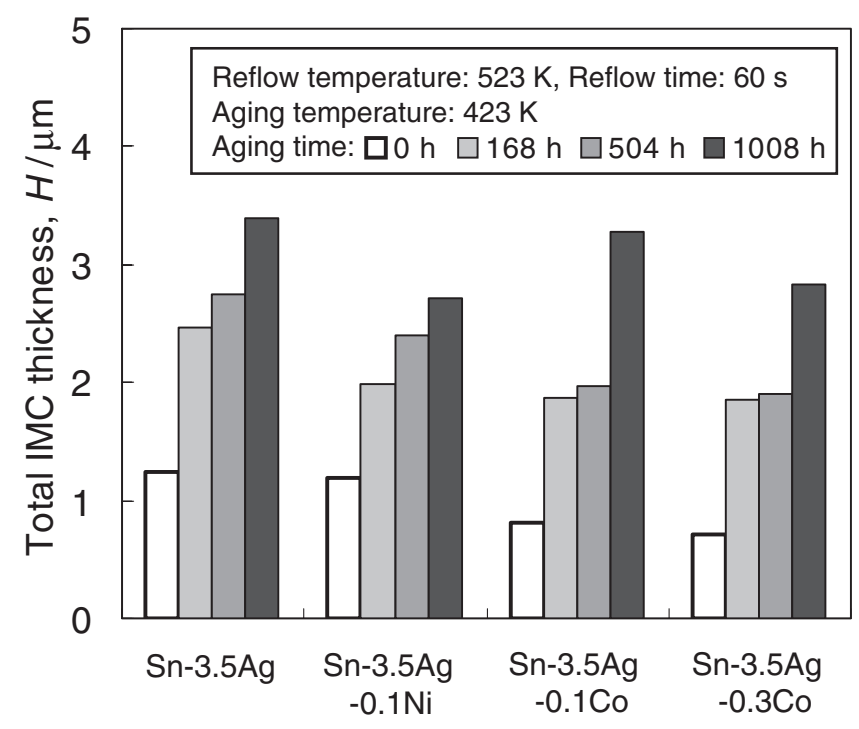

Fig. 7 Effect of aging time at $423 \mathrm{~K}$ on the total IMC thickness between the solder and Ni-P plating.

$\mathrm{Sn}-\mathrm{Ag}-\mathrm{Ni}$ or Co solder increased drastically as compared with that of the binary Sn-Ag solder. During aging process at $423 \mathrm{~K}$, total IMC thickness in all solders increased with the increase of the aging time. Especially, the growth rate of the IMC layer for the binary Sn-Ag solder was much greater than that for the Sn-Ag-Ni or Co solder. After aging process for $1008 \mathrm{~h}$, all the solders had similar IMC thickness. Within this test, the addition of $\mathrm{Ni}$ or $\mathrm{Co}$ to the solder was effective to reduce the growth rate of the IMC layer at the interface with $\mathrm{Cu}$ pad during aging process.

Figure 7 shows the total IMC thickness at the interface between the $\mathrm{Sn}-\mathrm{Ag}(-\mathrm{Ni}$ or $\mathrm{Co})$ solder and elecroless $\mathrm{Ni}-\mathrm{P}$ plating just after reflow and after aging process. Just after reflow process, regardless of the $\mathrm{Ni}$, Co addition, all the solders had almost similar IMC thickness, and the thickness was only $1 \mu \mathrm{m}$. Even after aging for $1008 \mathrm{~h}$, the IMC thickness was only $3 \mu \mathrm{m}$ for all the solders. The IMC thickness at the interface for electroless $\mathrm{Ni}-\mathrm{P}$ plating was clearly thinner than that for a bare $\mathrm{Cu}$ during the aging process. The addition of $\mathrm{Ni}$ or $\mathrm{Co}$ to the solder was not affected to the growth of IMC layer at the interface with electroless Ni-P plating during aging process.

Therefore, for using a $\mathrm{Cu}$ as a metallization layer of the substrate, the addition of $\mathrm{Ni}$ or Co was very effective for the IMC formation and growth at the interface during reflow and aging process. On the other hand, for using a electroless $\mathrm{Ni}-\mathrm{P}$ plating as a metallization layer of the substrate, the IMC formation and growth at the interface was not affected by the $\mathrm{Ni}$ or Co addition to the solder. These differences concerning the IMC layer are probably associated with the phase of the IMC formed at the interface and the substitution of $\mathrm{Ni}$ or $\mathrm{Co}$ for $\mathrm{Cu}$ atom in binary compounds with $\mathrm{Sn}, \mathrm{Cu}_{6} \mathrm{Sn}_{5}$.

\subsection{Joint strength of solder bump}

In order to evaluate the effect of the morphology of the IMC layer at the interface on the joint strength and the fracture mode of solder bumps, a bump pull test was performed. The pull test is a commonly employed method for estimating the strength of the joint interface. Figure 8 shows the average pull strengths of the $\mathrm{Sn}-\mathrm{Ag}(-\mathrm{Ni}$ or $\mathrm{Co})$ solder joints with a $\mathrm{Cu}$ pad and the effect of the aging time on the pull strength of the solder joints. The pull strength in all solders slightly degraded with the increase of the aging time. The addition of $\mathrm{Ni}$ or Co to the solder was not affect to the joint strength of the solder joints with a $\mathrm{Cu}$ pad, although, as shown in Figs. 2 and 4, the IMC morphology at the interface of the Sn-Ag-Ni or Co was quite different form that for the binary $\mathrm{Sn}-\mathrm{Ag}$ solder after reflow and aging process. After the bump pull test, fracture surfaces of the solder bump were observed, and the fracture could be clearly classified into two modes, fracture through the solder and fracture along the interface between the solder and pad. Figure 9 shows SEM image of the typical fracture along the interface between the solder and pad for the solder joint using Sn-3.5Ag-0.3Co solder. By EPMA analysis, it was confirmed that the fracture progressed among the interface between the solder and pad. Table 1 shows the ration of fracture along the interface with a

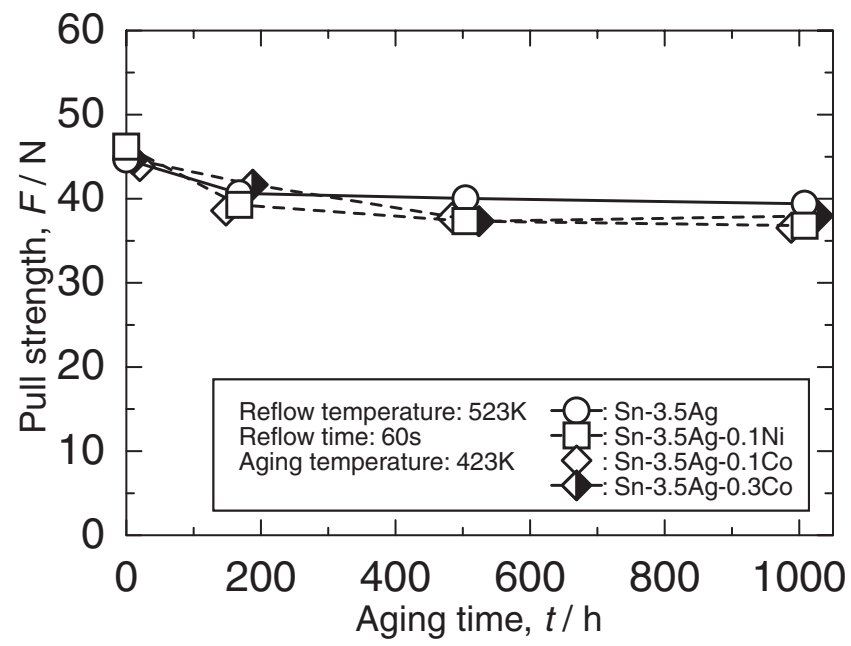

Fig. 8 Effect of aging time at $423 \mathrm{~K}$ on the pull strength of the solder $/ \mathrm{Cu}$ pad joint. 


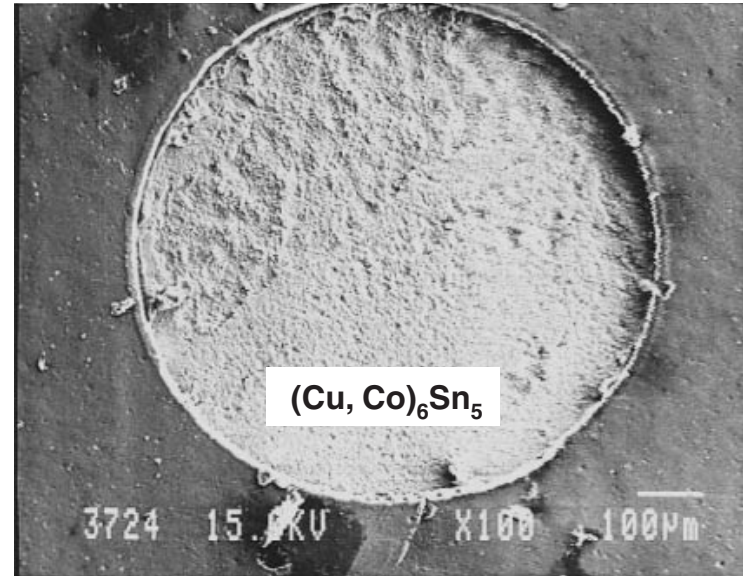

Fig. 9 SEM micrograph of typical fracture along the interface for the solder joint using Sn-Ag-0.3Co solder.

Table 1 Ration of fracture along the interface in 15 trials for each solder bump with a $\mathrm{Cu}$ pad.

\begin{tabular}{ccccc}
\hline Aging time (h) & Sn-3.5Ag & $\begin{array}{c}\text { Sn-3.5Ag } \\
-0.1 \mathrm{Ni}\end{array}$ & $\begin{array}{c}\text { Sn-3.5Ag } \\
-0.1 \mathrm{Co}\end{array}$ & $\begin{array}{c}\text { Sn-3.5Ag } \\
-0.3 \mathrm{Co}\end{array}$ \\
\hline 0 & 0 & $2 / 15$ & $6 / 15$ & $11 / 15$ \\
\hline 168 & 0 & $9 / 15$ & $7 / 15$ & $5 / 15$ \\
\hline 504 & 0 & $11 / 15$ & $9 / 15$ & $3 / 15$ \\
\hline 1008 & 0 & $14 / 15$ & $15 / 15$ & $6 / 15$ \\
\hline
\end{tabular}

$\mathrm{Cu}$ pad in 15 trials for each solder composition as a function of the aging time. The fracture mode of the $\mathrm{Sn}-\mathrm{Ag}-\mathrm{Ni}$ or $\mathrm{Co}$ solders was clearly different from that for the binary $\mathrm{Sn}-\mathrm{Ag}$ solder. For the $\mathrm{Sn}-\mathrm{Ag}$ solder joint, the fracture propagated through the solder in all tests after reflow and aging process. Meanwhile, for the $\mathrm{Sn}-\mathrm{Ag}-\mathrm{Ni}$ or Co solder joints, the fracture for some tests occurred along the interface, and the ration of fracture along the interface basically increased with increasing the aging time. The difference in fracture mode between $\mathrm{Sn}-\mathrm{Ag}$ solder joint and $\mathrm{Sn}-\mathrm{Ag}-\mathrm{Ni}$ or Co solder joint may be caused by the morphology of the IMC layer at the interface.

Figure 10 shows the average pull strengths of the Sn$\mathrm{Ag}(-\mathrm{Ni}$ or $\mathrm{Co})$ solder joints with a electroless Ni-P plating and the effect of the aging time on the pull strength of the solder joints. Just after reflow process, the pull strengths in all solders are almost similar. Then, during aging process, the pull strength of Sn-Ag-Co solder joints clearly degraded with the increase of the aging time and, particularly, the strength decreases considerably at the first stage of the aging period from $0 \mathrm{~h}$ to $108 \mathrm{~h}$ compared to the $\mathrm{Sn}-\mathrm{Ag}$ solder and the $\mathrm{Sn}-\mathrm{Ag}-\mathrm{Ni}$ solder. After aging process for $1008 \mathrm{~h}$, the pull strength of the Sn-Ag-Co solder joints was lower than that of the $\mathrm{Sn}-\mathrm{Ag}$ solder and the $\mathrm{Sn}-\mathrm{Ag}-\mathrm{Ni}$ solder joints. Table 2 shows the ration of fracture along the interface with an electroless Ni-P plating in 15 trials for each solder composition as a function of the aging time. Obviously, the fracture mode was difference between $\mathrm{Sn}-\mathrm{Ag}(-\mathrm{Ni})$ solders and $\mathrm{Sn}$ Ag-Co solders. In the case of Sn-Ag-Co solder, except one test, fracture propagated through the solder in all tests after reflow and aging process. The ration of fracture along the interface for Sn-Ag-Co solders was much more than that for

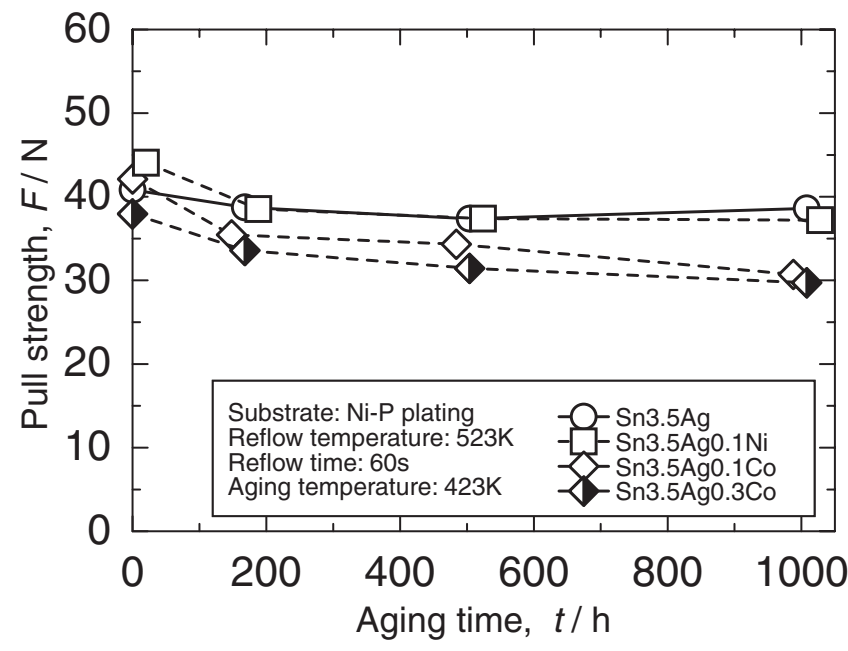

Fig. 10 Effect of aging time at $423 \mathrm{~K}$ on the pull strength of the solder/Ni$\mathrm{P}$ plating joint.

Table 2 Ration of fracture along the interface in 15 trials for each solder bump with a electroless Ni-P plating.

\begin{tabular}{ccccc}
\hline Aging time (h) & Sn-3.5Ag & $\begin{array}{c}\text { Sn-3.5Ag } \\
-0.1 \mathrm{Ni}\end{array}$ & $\begin{array}{c}\text { Sn-3.5Ag } \\
-0.1 \mathrm{Co}\end{array}$ & $\begin{array}{c}\text { Sn-3.5Ag } \\
-0.3 \mathrm{Co}\end{array}$ \\
\hline 0 & $8 / 15$ & $7 / 15$ & $14 / 15$ & $15 / 15$ \\
\hline 168 & 0 & $1 / 15$ & $15 / 15$ & $15 / 15$ \\
\hline 504 & $3 / 15$ & $1 / 15$ & $15 / 15$ & $15 / 15$ \\
\hline 1008 & 0 & $4 / 15$ & $15 / 15$ & $15 / 15$ \\
\hline
\end{tabular}

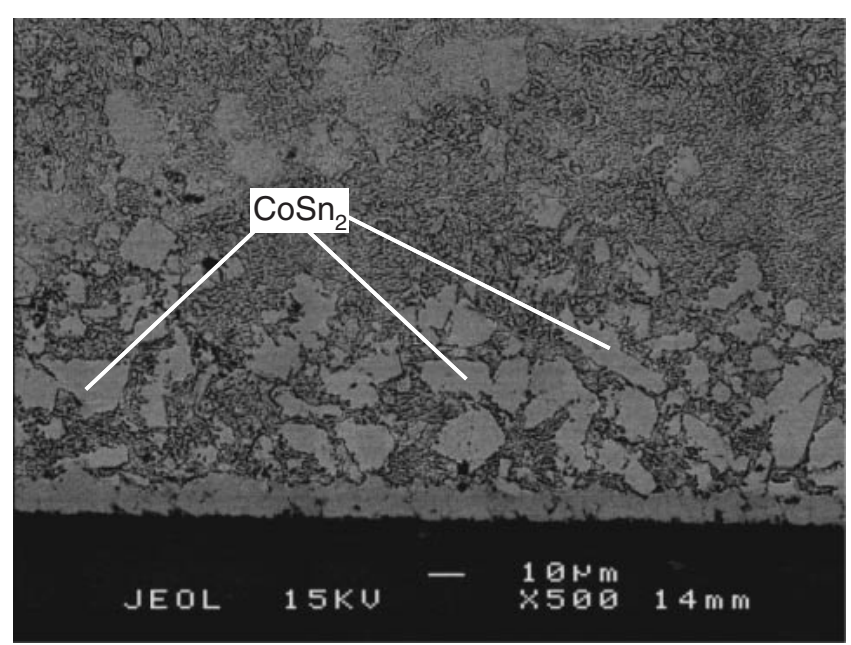

Fig. 11 SEM photographs of the interface between Sn-3.5Ag-0.3Co solder and electroless Ni-P plating using a low magnification.

$\mathrm{Sn}-\mathrm{Ag}(-\mathrm{Ni})$ solders. To interpret why the solder joint of the Sn-Ag-Co solders, except the Sn-Ag-Ni solder, showed the fracture along the interface, the interface between the SnAg-Co solder and electroless Ni-P plating was observed by using a low magnification SEM. The image at a low magnification was shown in Fig. 11. Many particles of IMC were observed in the solder matrix, and the composition of the IMCs was confirmed as $\mathrm{CoSn}_{2}$ phase. So in the case of Sn-Ag-Co solder joint with elecroless Ni-P plating, IMC particles were formed near the interface. So, the fracture 
along the interface may be attributed to the IMC particles near the interface due to the brittle property of the IMC.

Therefore, for using a $\mathrm{Cu}$ as a metallization layer of the substrate, the addition of $\mathrm{Ni}$ or Co to the solder did not affect the pull strength of the solder bump, but it did affect the fracture mode. On the other hand, for using an electroless Ni$P$ plating as a metallization layer of the substrate, the addition of $\mathrm{Co}$, except $\mathrm{Ni}$, was effective for the pull strength and the fracture mode during aging process.

\section{Conclusions}

The microstructure at the interface and the pull strength of $\mathrm{Sn}-\mathrm{Ag}(-\mathrm{Ni}$ or Co) solder bump were investigated to reveal the effect of the addition of $\mathrm{Ni}$ or Co to $\mathrm{Sn}-\mathrm{Ag}$ solder on the interface between the solder and metallization layer. As a metallization layer of the substrate, bare $\mathrm{Cu}$ and electroless $\mathrm{Ni}-\mathrm{P}$ plating were utilized. For using a $\mathrm{Cu}$ pad, the addition of $\mathrm{Ni}$ or $\mathrm{Co}$ was very effective for the IMC formation and growth at the interface during reflow and aging process. In terms of the joint strength with a $\mathrm{Cu}$ pad, the addition of $\mathrm{Ni}$ or Co to the solder did not affect the pull strength of the solder bump, but it did affect the fracture mode. In contrast, for using electroless Ni-P plating, the IMC formation and growth at the interface was not affected to the $\mathrm{Ni}$ or Co addition. And the addition of $\mathrm{Co}$, except $\mathrm{Ni}$, affected the pull strength and the fracture mode during aging process.

\section{Acknowledgment}

This work was partly supported by Grant-in-Aid for Cooperative Research Project of Nationwide Joint-Use Research Institute on Development Base of Joining Technology for New Metallic Glasses and Inorganic Materials from The Ministry of Education, Culture, Sports, Science and Technology, Japan.

\section{REFERENCES}

1) Official Journal of the European Union, February 13, (2003), L37/ 19-L37/23 L37/24-L37/38.

2) T. Takemoto: Materia Japan 35 (1996) 320-325.

3) T. Takemoto: J. Japan Weld Soc. 69 (2000) 100-107.

4) T. Takemoto and M. Miyazaki: Mater. Trans. 42 (2001) 745-750.

5) S. H. Huh, K. S. Kim and K. Suganuma: Mater. Trans. 42 (2001) 739-744.

6) W. K. Choi, S. W. Yoon and H. M. Lee: Mater. Trans. 42 (2001) 783-789.

7) S. W. Chen and Y. W. Yen: J. Electron. Mater. 30 (2001) 1133-1137.

8) J. W. Yoon and S. B Jung: J. Alloys Compd. 359 (2003) 202-208.

9) T. Takemoto and T. Funaki: Mater. Trans. 43 (2002) 1784-1790.

10) I. Shohji, T. Nakamura, F. Mori and S. Fujiuchi: Mater. Trans. 43 (2002) 1797-1801.

11) T. Takemoto, T. Uetani and M. Yamazaki: Soldering \& Surf. Mount Technol. 16 (2004) 9-15.

12) H. Nishikawa, T. Takemoto, K. Kifune, T. Uetani and N. Sekimori: Mater. Trans. 45 (2004) 741-746.

13) H. Nishikawa, A. Komatsu and T. Takemoto: Mater. Trans. 46 (2005) 2394-2399.

14) W. K. Choi, S. W. Yoon and H. M. Less: Mater. Trans. 42 (2001) 783-789.

15) I. E. Anderson, J. C. Foley, B. A. Cook, J. Harringa, R. L. Terpstra and O. Unal: J. Electron. Mater. 30 (2001) 1050-1059.

16) C. M. Chuang and K. L. Lin: J. Electron Mater. 32 (2003) 1426-1431.

17) T. H. Chuang, S. F. Yen and M. D. Cheng: J. Electron. Mater. 35 (2006) 302-309.

18) C. M. T. Law, C. M. L. Wu, D. Q. Yu, L. Wang and J. K. L. Lai: J. Electron. Mater. 35 (2006) 89-93.

19) S. T. Kao, Y. C. Lin and J. G. Duh: J. Electron. Mater. 35 (2006) 486-493.

20) S. K. Kang, D. Leonard, D. Y. Shin, L. Gignac, D. W. Henderson, S. Cho and J. Yu: J. Electron. Mater. 35 (2006) 479-485.

21) Y. C. Chan, A. C. K. So and J. K. L. Lai: Mater. Sci. Eng. B 55 (1998) $5-13$.

22) M. O. Alam, Y. C. Chan and K. C. Hung: Microelectronics Reliability 42 (2002) 1065-1073.

23) J. M. Koo and S. B. Jung: Microelectronic Eng. 82 (2005) 569-574.

24) F. Gao, T. Takemoto, H. Nishikawa and A. Komatsu: J. Electron Mater. 35 (2006) 905-911. 